ТЕОРЕТИЧНІ ПРОБЛЕМИ РОЗВИТКУ НАЦІОНАЛЬНОЇ ЕКОНОМІКИ

УДК 657:005.52

DOI: 10.25140/2411-5215-2021-2(26)-37-47

Галина Самійленко, Аліна Вітер

\title{
ТЕОРЕТИКО-МЕТОДОЛОГІЧНІ ЗАСАДИ УПРАВЛІНСЬКОГО АНАЛІЗУ ТА ЙОГО РОЛЬ У ПРИЙНЯТТІ УПРАВЛІНСЬКИХ РІШЕНЬ
}

\author{
Halyna Samiilenko, Alina Viter \\ THEORETICAL AND METHODOLOGICAL FUNDAMENTALS \\ OF MANAGEMENT ANALYSIS AND ITS ROLE \\ IN MANAGEMENT DECISION MAKING
}

\begin{abstract}
У статті розглянуто основні підходи до розуміння сутності поняття «управлінський аналіз» та їх комбіначії, сформульовано його особливості. Визначені такі сутнісні складові управлінського аналізу, як мета, завдання, предмет, об'єкт, суб 'єкт, користувачі, функиії, що дає можливість його виділення в самостійну галузь знань та напрям практичної діяльності. Розглянуто методологічну базу управлінського аналізу, з'ясовано ї̈ направленість на отримання чисельної аналітичної інформації, альтернативних варіантів рімень та залежність від бізнес-процесів, стратегії та системи управління підприємством. У мезсах дослідження методологічних засад управлінського аналізу систематизовано методи та сформульовано його базові приниини, поєднання яких слід вважати основою методології. 3 'ясовано провідну роль та визначальне місце управлінського аналізу в прочесі прийняття управлінських рішень.

Ключові слова: аналіз; управлінський аналіз; принципи; методи; управління; прийняття управлінських рішень.

Рис.: 3. Табл.: 2. Бібл.: 13.

The main approaches to understanding the essence of the concept of "management analysis" and their combinations are considered, its features are formulated. The essential components of management analysis are defined as the purpose, tasks, subject, object, subject, users, functions, which allows its allocation to an independent field of knowledge and direction of practical activity. The methodological basis of management analysis is considered, its orientation to obtain numerical analytical information and alternative solutions and dependence on business processes, strategy and management system of the enterprise is clarified. should be considered the basis of the methodology. The leading role and defining place of managerial analysis in the process of making managerial decisions is clarified.
\end{abstract}

Keywords: analysis; management analysis; principles; methods; management; management decisions.

Fig.: 3. Table: 2. References: 13.

JEL Classification: M400; M410

Постановка проблеми. Управлінський процес полягає у своєчасному отримані керівниками релевантної інформації, яка необхідна їм для прийняття ефективних рішень. Знаходження, формування та надання подібних даних можна вважати пріоритетним напрямом управлінського аналізу, виникнення та подальший розвиток якого пов'язаний передусім з управлінськими потребами.

Досягнення будь-якої мети підприємства можливо лише при іiі реальному плануванні, визначенні ресурсних потреб та шляхів ії реалізації, а також плідній праці робітників, яка можлива за умов гарної організації роботи персоналу та контролю за їхньою діяльністю для виявлення відхилень між фактичними результатами та запланованими. У випадку виявлення значних розбіжностей здійснюється регулювання, тобто відбувається корегування діяльності організації або планів, зважаючи на причини виявлених відхилень. Для реалізації розглянутих вище функцій управління насамперед необхідна інформація щодо протікання господарської діяльності підприємства, яка виявляється, накопичується, систематизується та трансформується в дані в різноманітних розрізах, потрібних керівникові для прийняття рішень, що являє собою систему управлінського аналізу. Управлінський аналіз орієнтований на задоволення потреб управління як стратегічного, так і поточного, оптимізацію ресурсів, що використовує підприємство та достовірну оцінку функціонування як певних структурних підрозділів, так і окремих керівників. Отже, головною метою управлінського обліку є допомога керівникам підприємства в прийнятті ефективних управлінських рішень та досягненні цілей організації.

Розвиток ринкової економіки в Україні, інтеграція їі у світовий економічний простір викликає підвищення потреби в інформації, яка необхідна для прийняття управлінських рішень, планування діяльності та здійснення контролю за нею. 3 урахуванням цього

(C) Самійленко Г. М., Вітер А. А., 2021 
спостерігається зростання зацікавленості керівників до управлінського аналізу та можливості його застосування на підприємствах. Водночас сьогодні запровадження управлінського аналізу як практичної діяльності на вітчизняні підприємства стримує багато факторів, серед яких особливо треба зазначити такий, як відсутність потрібних знань у керівників вищого та середнього рівня. Отже, одним із визначальних чинників та вирішальною умовою застосування та використання управлінського аналізу на певному підприємстві є розуміння важливості та необхідності його практичної реалізації з боку вищого керівництва компанії.

Аналіз останніх досліджень і публікацій. Дослідженню сутності управлінського аналізу та його значення в системі управління підприємством присвячені роботи таких закордонних та вітчизняних учених, як С. Бороненкова, М. Вахрушена, О. Гайдаєнко, 3. Герасимчук, В. Ільчук, О. Томчук, Н. Шевчук, А. Шеремет, Р. Федорович тощо.

Виділення недосліджених частин загальної проблеми. Досліджені роботи із сутності та змісту управлінського аналізу показали, що вони недостатньо розкривають питання його теоретичних основ та методологічних засад, а також у них не повною мірою визначається його роль та місце в управлінському процесі, зокрема в частині прийняття управлінських рішень, тому, на нашу думку, самі ці питання потребують подальшого вивчення.

Метою статті $\epsilon$ дослідження теоретико-методологічних засад управлінського аналізу та з'ясування його ролі та місця в процесі прийняття управлінських рішень.

Виклад основного матеріалу. Ефективність функціонування підприємства та його прибутковість у сучасних умовах багато в чому залежить від впровадження інноваційних підходів до його діяльності. При цьому окрему та важливу роль відіграє саме управлінський аналіз, який є основою для прийняття управлінських рішень, складання планів і здійснення контролю за їх виконанням, формування та реалізації стратегії, здійснення регулювання, внесення корективів, знаходження резервів підвищення ефективності операційної діяльності та оцінки становища та можливостей підприємства на ринку $[1 ; 2]$.

Поняття аналізу походить з грецької мови та в перекладі означає розкладання, розчленовування [3], тобто під ним слід розуміти поділ, розділення цілого на частини, складові для подальшого їх вивчення та дослідження. Аналіз є методом наукового пізнання, науковим напрямом, який виник унаслідок розмежування суспільних наук. Аналіз як функцію вивчали передусім у межах таких дисциплін, як бухгалтерський облік, статистика, фінанси, проте подальші трансформації сучасних економічних систем призвели до того, що зазначені галузі знань не змогли повною мірою задовольнити ті практичні моменти, які стали виникати. Унаслідок чого аналіз був виокремлений у самостійну дисципліну, яка дістала назву «економічний аналіз», під яким у загальному сенсі розуміють спеціальний вид економічних досліджень, що виявляють взаємозв'язок економічногосподарських процесів на підприємстві для його ефективного функціонування [4]. В умовах ринкової економіки та посилення впливу зовнішніх факторів на діяльність будьякої компанії, виникає потреба у веденні обгрунтованої управлінської діяльності, яка б сприяла оптимізації внутрішніх ресурсів, виявленню можливостей та переваг підприємства. Таким чином, у зазначених умовах великого значення набуває знаходження та застосовування безпосередньо на практиці нових підходів до управлінської діяльності, що базуються на даних аналізу, інформація якого є основою для ефективного управління підприємством та прийняття управлінських рішень. Сьогодні з'явилася потреба в всеохоплюючій, різнобічній інформації щодо різноманітних ресурсів компанії та ії результативних показників діяльності, яка необхідна керівникам підприємства для прийняття своєчасних та результативних управлінських рішень. Унаслідок цього виник напрям внутрішньої аналітичної діяльності - управлінський аналіз. Це поняття прийшло в Україну із-за закордону, закордонні дослідники під ним розуміли насамперед аналіз ви- 
ТЕОРЕТИЧНІ ПРОБЛЕМИ РОЗВИТКУ НАЦІОНАЛЬНОЇ ЕКОНОМІКИ

трат для складання планів, знаходження відхилень, складання калькуляцій тощо, проте для прийняття управлінських рішень такої інформації замало. В управлінський аналіз почали вкладати більш широкий сенс - підготовка та подання внутрішнім користувачам (керівникам різних рівнів управління тощо) різноманітної релевантної інформації про внутрішній стан системи, окремих ії̈ складових задля прийняття ефективних управлінських рішень. Нині серед учених не має єдиної думки щодо поняття управлінського аналізу, існують різні його визначення (табл. 1).

Таблиця 1

Визначення поняття «управлінський аналіз»

\begin{tabular}{|c|c|c|}
\hline Автор & Визначення & Джерело \\
\hline Р.В.Федорович & $\begin{array}{l}\text { вид економічного аналізу під час використання як класифікаційної } \\
\text { ознаки типу використовуваної інформації }\end{array}$ & {$[4$, c. 149$]$} \\
\hline А. Д. Шеремет & $\begin{array}{l}\text { внутрішній управлінський аналіз - частина управлінського обліку, } \\
\text { тобто інформаційно-аналітичного забезпечення адміністрації, керівни- } \\
\text { цтва підприємством }\end{array}$ & {$[5$, c. 211$]$} \\
\hline М. А. Вахрушина & $\begin{array}{l}\text { управлінський аналіз - внутрішній економічний аналіз, спрямований } \\
\text { на оцінку як минулих, так і майбутніх результатів господарювання } \\
\text { структурних підрозділів підприємства }\end{array}$ & {$[6$, c. 29] } \\
\hline $\begin{array}{l}\text { 3. В. Герасимчук } \\
\text { та ін. }\end{array}$ & $\begin{array}{l}\text { предметна галузь знань, спрямована на комплексне дослідження сис- } \\
\text { теми управління підприємством, що забезпечує ефективну реалізацію } \\
\text { функцій управління та прийняття оптимальних управлінських рішень, } \\
\text { досягнення стратегічних, тактичних і оперативних цілей підприємства }\end{array}$ & [7] \\
\hline $\begin{array}{l}\text { О. М. Гайдаєнко, } \\
\text { Н. С. Шевчук }\end{array}$ & $\begin{array}{l}\text { управлінський аналіз - це комплексний аналіз внутрішніх ресурсів і } \\
\text { зовнішніх можливостей підприємства, спрямований на оцінку поточ- } \\
\text { ного стану бізнесу, його сильних і слабких сторін, виявлення стратегі- } \\
\text { чних проблем }\end{array}$ & [8] \\
\hline С. А. Бороненкова & $\begin{array}{l}\text { внутрішній аналіз, що орієнтований на досягнення мети керівника, } \\
\text { спрямований на кінцевий результат лише у межах своїх об’єктів рі- } \\
\text { шень; супроводжує управлінський облік, базується на його інформації, } \\
\text { забезпечуючи прийняття управлінських рішень }\end{array}$ & {$[9$, c. 9$]$} \\
\hline $\begin{array}{l}\text { Є. М. Сич, } \\
\text { Г. В. Кравчук, } \\
\text { В. П. Ільчук }\end{array}$ & $\begin{array}{l}\text { внутрішньогосподарський виробничий аналіз, який являє собою систему } \\
\text { способів накопичення, опрацювання, трансформації та використання } \\
\text { інформації управлінського характеру } 3 \text { метою забезпечення життєдіяль- } \\
\text { ності суб'єкта господарювання в умовах дії ринку та конкуренції }\end{array}$ & {$[10]$} \\
\hline
\end{tabular}

Наведені в табл. 1 трактування дефініції «управлінський аналіз» та їх вивчення дає змогу зробити такі висновки:

- відсутність єдиного розуміння вищезазначеного поняття в науковому середовищі;

- ця категорія є складною, багатоаспектною та багатогранною;

- відповідно до наведеного різноманіття визначень терміна можна виокремити такі основні підходи до його розуміння (рис. 1).

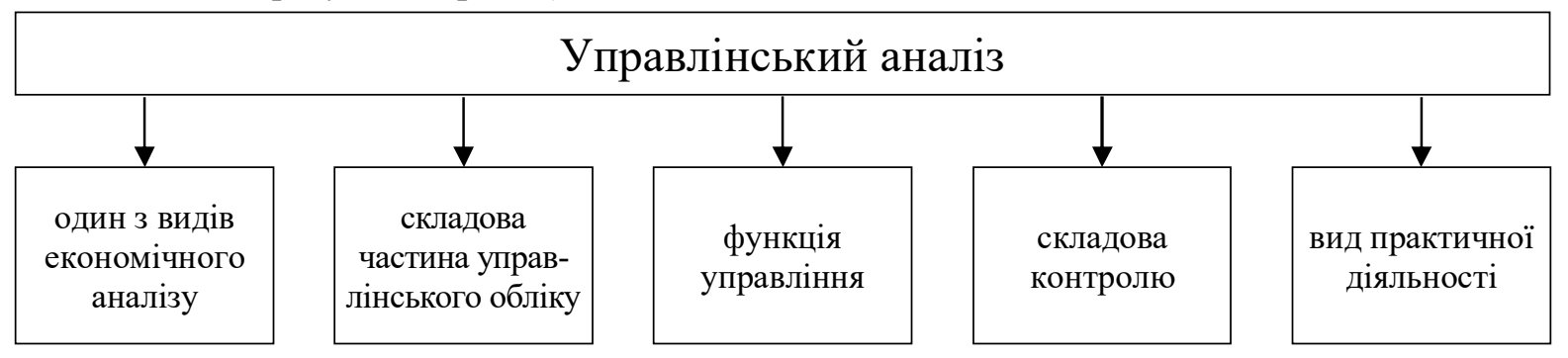

Рис. 1. Підходи до розуміння управлінського аналізу

Джерело: сформовано авторами на підставі [4-10].

Згідно з підходами, відображеними на рис. 1, такі вчені, як Є. Мних, Г. Савицька, М. Чумаченко, А. Шеремет та інші дотримуються думки, що управлінський аналіз - це вид економічного аналізу, який виділився в окремий напрям у зв'язку зі зростанням зна- 
чущості управлінської діяльності в межах підприємств та потреби керівників організацій у різноманітній внутрішній інформації, трансформованій певним чином та представленій у різноманітних видах, яка необхідна для прийняття управлінських рішень. Одним із визначальних чинників поділу економічного аналізу на фінансовий та управлінський $є$ їх інформаційна основа. Так, дані фінансового аналізу є доволі стандартними та водночас транспарентними, спрямованими на зовнішніх користувачів, тоді як інформація управлінського аналізу не $\epsilon$ стандартизованою, є виключно внутрішньою для іiї використання керівниками підприємства при прийнятті ними обгрунтованих управлінських рішень.

Інших підхід, якого дотримуються такі дослідники, як С. Бороненкова, М. Любушин та інші, полягає в розгляді управлінського аналізу як складової частини управлінського обліку. Цей підхід заснований на думці, що інформаційною базою управлінського аналізу є управлінський облік.

Наступним є підхід, що визначає управлінський аналіз як функцію управління, ототожнює ці поняття, на основі чого робиться висновок про те, що це забезпечує наукову основу при прийнятті управлінських рішень. Цей підхід пов'язаний з іншим, який розглядає управлінський аналіз як частину контролю, до якого схиляються такі вчені, як Г. Герасименко, Т. Головіна, Е. Маркар'ян, С. Маркар'ян тощо. Не можна заперечувати наявність взаємозв'язку між аналізом та контролем, проте такий стан речей, на наш погляд, не дає підстав вважати управлінській аналіз підсистемою контролю, оскільки він значно ширше й не обмежуються лише функцією контролю.

Також можна виділити підхід, який розглядає управлінський аналіз як спосіб налагодження взаємодії між суб'єктом та об'єктом управління для реалізації управлінського процесу та досягненням поставленої мети. Підхід пов'язаний зі застосуванням системного підходу до управлінського аналізу та розглядом його як окремої практичної діяльності в межах підприємства.

Також, крім підходів, зазначених на рис. 1, існують i їх комбінації. Так, М. Вахрушина дотримується думки, що управлінський аналіз - це і вид економічного аналізу, і складова управлінського обліку [6].

Крім того, на наше переконання, особливої уваги заслуговує визначення, яке запропоновано колективом авторів на чолі із З. Герасимчук, які розглядають управлінський аналіз як спеціальну, окрему предметну галузь знань, що спрямована на реалізацію функцій управління завдяки чому здійснюється прийняття ефективних управлінських рішень та досягаються поставлені цілі підприємства [7].

Отже, у загальному сенсі управлінський аналіз - це аналіз операційної діяльності підприємства та іiі складових, який проводиться для прийняття керівниками обгрунтованих, своєчасних та ефективних управлінських рішень.

Дослідження існуючих підходів до розуміння управлінського аналізу дає змогу сформулювати його особливості:

- управлінський аналіз застосовується лише на мікрорівні (на рівні підприємства);

- головними користувачами інформації управлінського аналізу є керівники різних рівнів;

- дані управлінського аналізу є внутрішньою інформацією певного підприємства, яка часто може являти собою комерційну таємницю;

- інформація управлінського аналізу впливає на дії керівників та на рішення, які вони приймають;

- дані управлінського аналізу можуть бути представлені в різноманітному вигляді, подання яких не має сталої періодичності, та нестандартизовані, містять докладну, розгорнуту, своєчасну та релевантну для прийняття управлінських рішень інформацію.

Для більш глибоко розуміння сутності та змісту управлінського аналізу, на нашу думку, необхідно не лише з'ясувати поняття та підходи до його розуміння, а також окреслити основні елементи, на кшталт, мети, завдань, предмета, об’єкта, суб’єкта тощо (табл. 2). 
Сутнісні складові управлінського аналізу

\begin{tabular}{|l|l|}
\hline \multicolumn{1}{|c|}{ Елементи } & \multicolumn{1}{|c|}{ Сутність } \\
\hline Мета & $\begin{array}{l}\text { знаходження шляхів отримання максимальної прибутковості підприємства, підвищення } \\
\text { ефективності операційної діяльності та рівня конкурентоспроможності підприємства, } \\
\text { прийняття управлінських рішень для досягнення визначених цілей }\end{array}$ \\
\hline Завдання & $\begin{array}{l}\text { визначення частки ринку підприємства на основі його можливостей; } \\
\text { виялення ресурсного потенціалу підприємства щодо обсягу виробництва та (або) про- } \\
\text { дажу за рахунок їх кращого використання; } \\
\text { - здійснення оцінки результатів операційної діяльності та пошук шляхів іх пришвидшення; } \\
\text { - розробка стратегії управління витратністю підприємства та політики ціноутворення; } \\
\text { - досягнення беззбитковості операційної діяльності на основі знаходження оптимального } \\
\text { взаємозв’язку між обсягом продажу, витратами та прибутковістю }\end{array}$ \\
\hline Предмет & результати господарської діяльності підприємства \\
\hline Об’єкт & процеси господарювання на підприємстві, що спрямовані на досягнення його цілей \\
\hline Суб’єкт & $\begin{array}{l}\text { структурні підрозділи підприємства, які займаються аналітичною діяльністю та окремі } \\
\text { посадові особи, що несуть відповідальність за здійснення аналізу, а також зовнішній } \\
\text { консалтинг з аналітичної роботи }\end{array}$ \\
\hline Користувачі & апарат управління (керівники різних рівнів управління), власники \\
\hline Функції & $\begin{array}{l}\text { інфомаційна - надання суб’єктам управлінського аналізу потрібної для прийняття } \\
\text { управлінських рішень інформації; } \\
\text { контрольна - здійснення контролю за досягнутими результатами, виявлення невідповід- } \\
\text { ностей; } \\
\text { оціночна - здійснення оцінки фактичних показників функціонування підприємства у по- } \\
\text { рівнянні з плановими; } \\
\text { прогнозна - розробка прогнозних показників діяльності підприємства на основі їх фак- } \\
\text { тичного стану }\end{array}$ \\
\hline
\end{tabular}

Джерело: розроблено авторами на підставі $[7 ; 8 ; 11 ; 12]$.

Дані табл. 2 показують, що сьогодні управлінський аналіз - це окрема галузь знань та напрям практичної діяльності підприємства, що спрямовані на прийняття результативних управлінських рішень для досягнення головної мети кожної компанії: отримання та збільшення прибутку, а також зниження витратності, підвищення конкурентоспроможності тощо.

У межах цього дослідження необхідно розглянути методологічні засади управлінського аналізу. На наш погляд, методологія управлінського аналізу грунтується на інтегральній системі економічного аналізу, що полягає у використанні керівниками певної інформації в різних розрізах, видах та поєднаннях при прийнятті управлінських рішень щодо досягнення різноманітних цілей. При цьому методологічні основи економічного аналізу містять стандартизовані процедури, спрямовані здебільшого для констатування фактів та розрахунку певних показників діяльності підприємства минулих періодів. Методологічні засади управлінського аналізу при цьому є більш гнучкими та адаптивними, спираються та залежать від бізнес-технології, стратегічного управління та організаційної структури підприємства, що відображає стан системи управління. Методологічна база управлінського аналізу в сучасних умовах повинна забезпечувати перманентний розвиток компанії, що неодмінно приводить до виникнення інноваційних підходів, методів та форм прийняття управлінських рішень. Методологія управлінського аналізу спрямована на отримання великого обсягу аналітичних даних для прийняття обгрунтованих рішень та досягнення ефективних результатів роботи підприємства. Крім того, методологія управлінського аналізу повинна бути націлена на отримання великої кількості альтернативних варіантів рішень. При цьому великого значення набуває інформаційна база, яка повинна забезпечувати ефективний управлінський процес і бути відповідною до потреб підприємства. А отже, при утворенні інформаційної складової управлінської діяльності необхідно дотримувати такого правила: максимальна кількість інформації при мінімальній кількості звітних внутрішніх документів. Отже, новітні концептуальні положення методології передбачають більшу гнучкість та інформатив- 
ність за рахунок чого буде досягнене об'єктивне представлення результатів господарювання підприємства. Концептуальні засади методології управлінського аналізу залежать від набору методів, обраних для реалізації стратегії підприємства. Методи управлінського аналізу повинні являти собою систему, метою якої є покращення управлінської діяльності підприємства як провідного іiї результату та досягнення.

Методи, які використовуються управлінським аналізом, містять досить широкий перелік, який пропонуємо поділити на дві групи: соціологічні та аналітичні (рис. 2). Соціологічні методи, до яких належать методи опитування, спостереження, експерименту та дослідження документів - це група методів, при застосуванні яких відбувається збір інформації, необхідної для проведення аналізу. До другої групи відносяться такі аналітичні методи (методи , які спрямовані на виявлення кореляції між умовами ведення господарської діяльності і іiі результатами), як порівняння, індексний, балансовий, факторний, функціонально-вартісний, графічний, маржинальний, статистичний тощо. При цьому в практичній діяльності підприємств найбільш поширеними є метод порівняння та факторний аналіз. Метод порівняльного аналізу полягає у зіставленні фактичного стану соціально-економічного об'єкта або його складових із минулими та прогнозними даними, а також із даними інших соціально-економічних об'єктів. Часте застосування цього методу пояснюється його простотою та наочністю, проте він не спроможний виявити причинно-наслідкові зв'язки, що впливають на розвиток певного підприємства. Цей недолік усувається при застосуванні факторного методу, який дозволяє виявити причини, які привели до певного результату чи результатів.

Крім методів, необхідно розглянути і принципи управлінського аналізу, які розробляються та формулюються вітчизняними та закордонними науковцями, оскільки управлінський аналіз не має ні державних, ні міжнародних стандартів. Серед принципів управлінського аналізу, які сформовані, зважаючи на його сутність, передусім виділимо такі:

- принцип системності - передбачає розгляд усіх процесів підприємства та отриманих результатів як складної системи, що, по-перше, змінюється в часі, а по-друге, взаємодіє із зовнішнім середовищем, по-третє, складається із взаємопов'язаних елементів;

- принцип науковості - полягає в проведенні аналітичної діяльності підприємства за допомогою новітніх інформаційних технологій, методів та процедур;

- принцип ефективності - базується на перевищенні доходів, отриманих за рахунок проведення аналізу, над витратами аналітичної діяльності;

- принцип комплексності - грунтується на тому, що беруться до уваги всі складові об'єкта аналізу з урахуванням різноманітних методик та процедур;

- принцип об'єктивності - означає, що аналіз повинний грунтуватися на правдивій, своєчасній, релевантній інформації, яка об'єктивно та точно описує певний процес чи елемент, та не містить зайвих, неправдивих даних, що заважають оперативному прийняттю рішень;

- принцип цілеспрямованості - полягає в спрямуванні проведення аналізу на реалізацію поставлених цілей підприємства;

- принцип оперативності - передбачає, що проведення аналізу повинно відбуватися швидко, на основі якого керівника підприємства зможуть приймати своєчасні управлінські рішення;

- принцип збалансованості - полягає в оптимізації співвідношення цілей та засобів їх досягнення, потрібної інформації та методів її розрахунку для отримання найкращих результатів діяльності підприємства;

- принцип адаптивності - полягає в можливості пристосування процедур, методів та джерел інформації до змін, які відбуваються всередині підприємства під впливом факторів зовнішнього середовища та швидко реагувати на них. 
ТЕОРЕТИЧНІ ПРОБЛЕМИ РОЗВИТКУ НАЦІОНАЛЬНОЇ ЕКОНОМІКИ

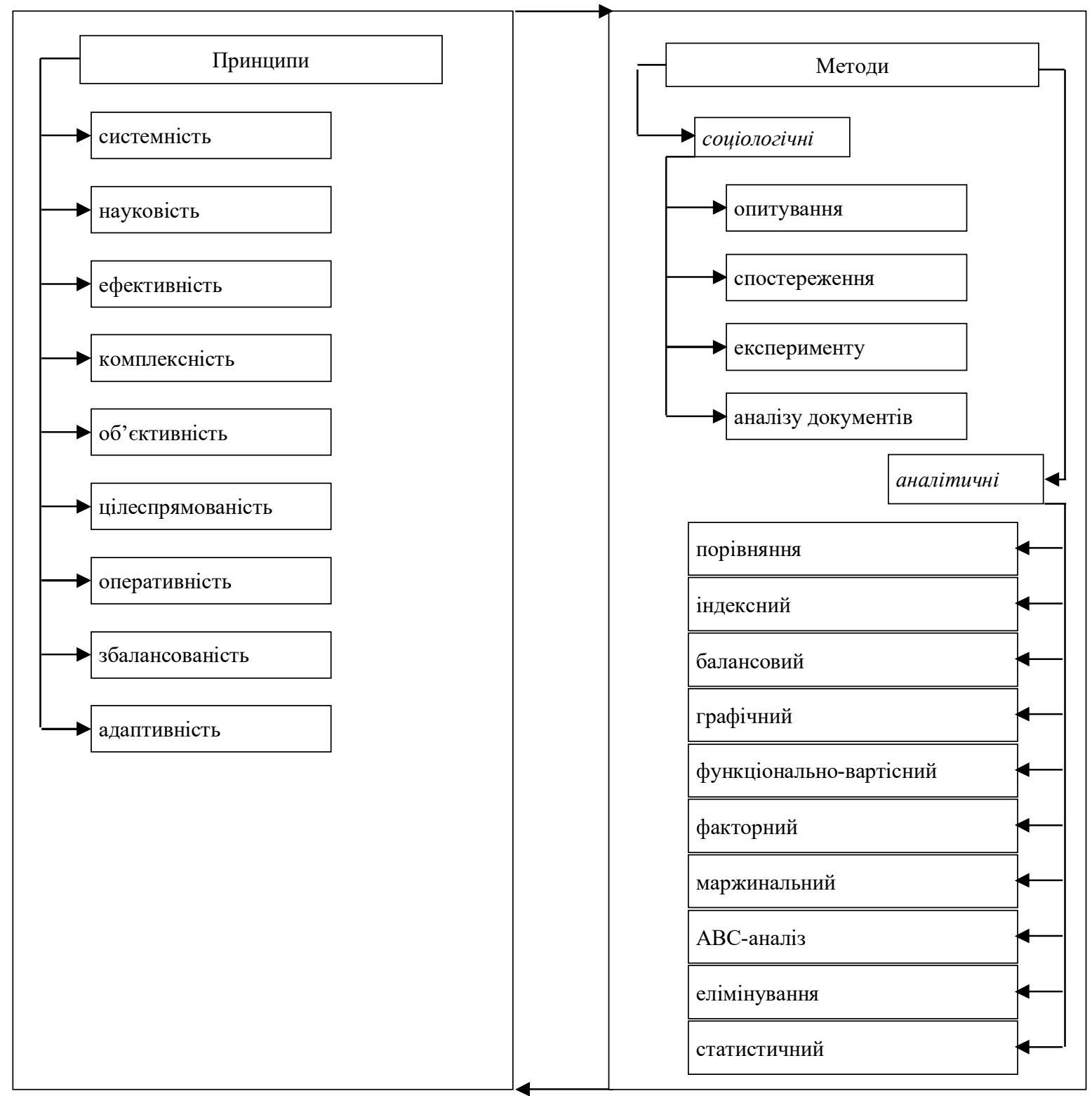

Рис. 2. Визначальні складові методології управлінського аналізу

Джерело: сформовано авторами на підставі [6-9; 11; 13].

Сформовані базові принципи управлінського аналізу як системи грунтується на розумінні того, що вони повинні спиратися та забезпечувати оперативні та релевантні дані задля прийняття своєчасних управлінських рішень на користь підприємства. Зазначимо, що визначені принципи управлінського аналізу не є сталими, вони можуть бути розширеними та доповненими в умовах зміни функціонування підприємства та зовнішнього середовища.

Реалізація зазначених принципів, на наш погляд, - це забезпечення економічного розвитку підприємства в умовах невизначеності та посилення впливу факторів зовнішнього середовища.

Важливим питанням у межах цього дослідження є визначення ролі й місця управлінського аналізу в управлінській діяльності підприємства, зокрема в процесі прийняття управлінських рішень. На рис. 3 зображено підприємство у вигляді відкритою складної системи, яка, по-перше, залежить від проявів зовнішнього середовища, а по-друге, складається з двох взаємопов'язаних між собою підсистем - управляючої та керованої. 


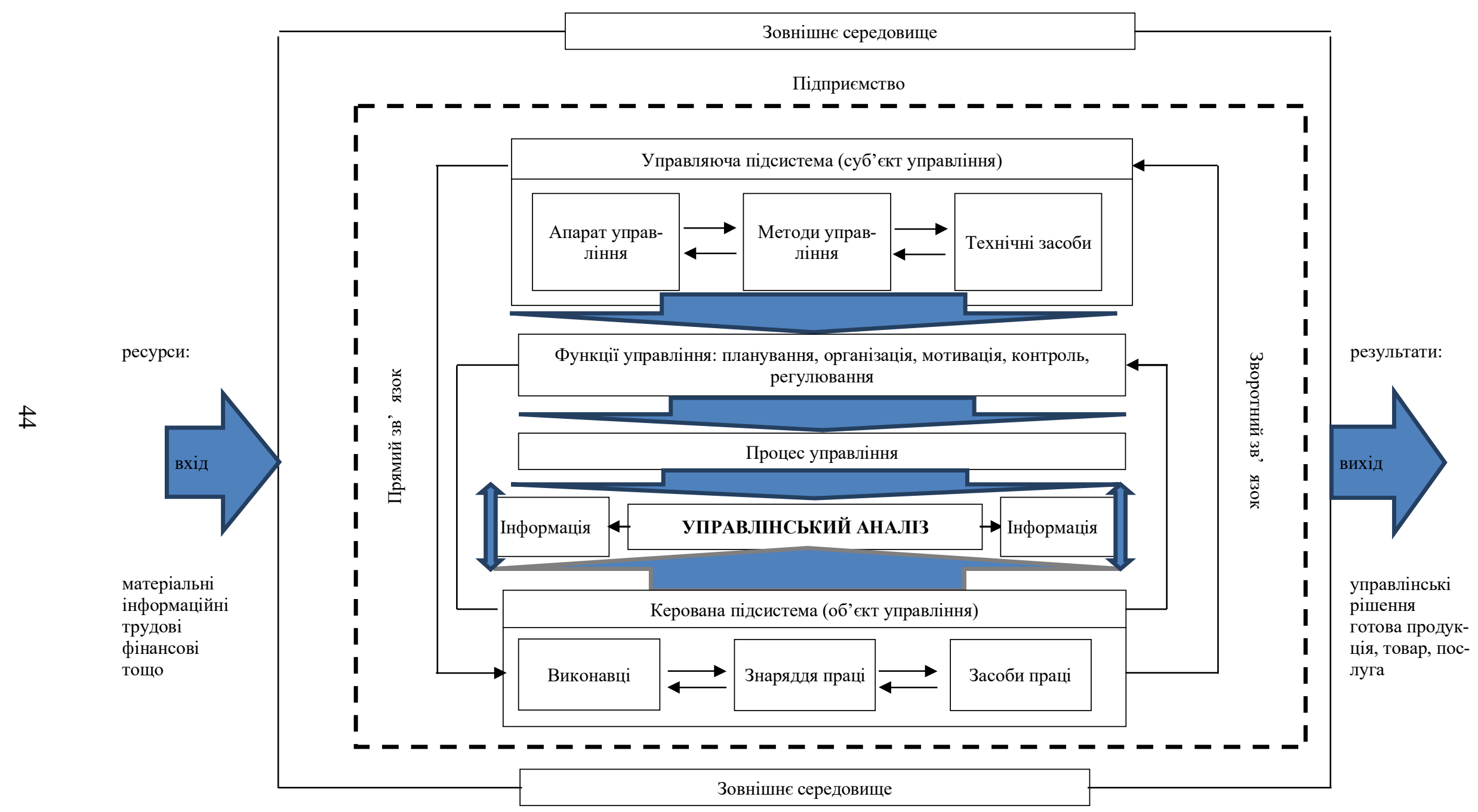

Рис. 3. Місие управлінського аналізу в процесі управління підприємством та прийнятті управлінських рімень Джерело: сформовано авторами на підставі [6-11; 13]. 
ТЕОРЕТИЧНІ ПРОБЛЕМИ РОЗВИТКУ НАЦІОНАЛЬНОЇ ЕКОНОМІКИ

Розгляд підприємства як відкритої системи означає, що воно відчуває постійний влив з боку зовнішнього середовища та взаємодіє з ним, обмінюючись різноманітними ресурсами через вхід та результати свої діяльності через вихід. Причому процес перетворення ресурсів у певний результат залежить від ефективності та якості управлінської діяльності підприємства. Представлення підприємства як складної системи дозволяє виділити дві підсистеми: ту, яка здійснює керівний плив (суб'єкт управління) та ту, на яку цей вплив спрямований (об'єкт управління). Управляюча підсистема здійснює постановку мети і задач для керованої підсистеми, контролює та регулює їх виконання, реалізуючи управлінські функції, керована підсистема, у свою чергу, через зворотний зв'язок звітує про виконання роботи. Завдання управлінського аналізу при цьому полягають в логічній обробці даних, їх узагальненні, систематизації, формулюванні певних висновків та пропозицій, тобто формування такої інформації, яка б була корисна для прийняття управлінського рішення та забезпечила б його обгрунтованість та ефективність.

Отже, управлінський аналіз посідає проміжне положення в системі управління між обробкою інформації та прийняттям рішення та прямо впливає на його якість. Процес розробки, прийняття та реалізації управлінського рішення вимагає змістовного управлінського аналізу, що забезпечує: обгрунтованість планування, визначення шляхів досягнення результатів, вибір методів для реалізації цілей, налагодження взаємозв'язків між об'єктами управління, вибір найефективнішого варіанту рішення, зменшення невизначеності та ризику. Таким чином, ефективність прийняття управлінських рішень залежить від якості інформаційного забезпечення системи управлінського аналізу.

Висновки і пропозиції. У процесі дослідження 3'ясовано відсутність єдиного визначення поняття «управлінський аналіз» та виокремлені існуючи підходи до його розуміння, на основі яких встановлено, що управлінський аналіз розглядають і як вид економічного аналізу, і як складову управлінського облікового комплексу, і як функцію управління тощо, а також як поєднання вищезазначених підходів, що дає змогу розглядати його як окрему галузь знань та напрям практичної діяльності.

Визначено, що на сучасному етапі економічного розвитку, методологія управлінського аналізу повинна спрямовуватися на покращення функціонування підприємства на засадах інформативності, інноваційності, гнучкості та адаптивності. У межах концептуальних засад методології було згруповано методи, які пропонується поділити на дві групи: соціологічні та аналітичні та розроблені базові принципи, перелік яких може бути доповнений за необхідністю.

Відносно ролі управлінського аналізу в процесі прийняття рішень, в даному дослідженні визначено, що він інформаційно супроводжує весь управлінський цикл, керівники різних рівнів управління використовують його інформацію для прийняття управлінських рішень 3 отримання майбутніх результативних показників діяльності підприємства.

Практична реалізація управлінського аналізу полягає в проведенні передусім перспективного його розділу в частині різноманітних ресурсів та результатів господарської діяльності підприємства для забезпечення інформацією процес прийняття управлінських рішень. Інформація управлінського аналізу повинна бути підготовлена та надана керівникам у такому вигляді, щоб надати їй найбільшого аналітичного змісту та релевантності залежно від мети та рівня управління. Отже, управлінський аналіз у сучасних умовах функціонування підприємств повинен стати базою для управлінської діяльності та забезпечувати інформаційну підтримку управління.

Багатоаспектність та складність управлінського аналізу вказує на необхідність подальшого удосконалення теоретико-методологічних засад та практичної діяльності 3 його реалізації з урахуванням сучасних викликів зовнішнього середовища, потреб управління та специфіки функціонування підприємств. 


\section{Список використаних джерел}

1. Кичко I. І., Холодницька А. В. Мотиваційний імператив реалізації управлінських компетенцій та збалансування ринку праці в Україні. Проблеми і перспективи економіки та управління. 2021. № 1 (25). С. 7-14.

2. Кичко І., Парубець О., Холодницька А., Пермінова В., Литвин С. Формування управлінських компетенцій керівників та їх вплив на конкурентоспроможність фірми і ринок праці в Україні. Фінансово-кредитна діяльність: проблеми теорії та практики. 2021 № 4(39). С. 284-293. URL: https://doi.org/10.18371/.v4i39.241317.

3. Поліщук О. П. Аналіз і синтез. Велика українська енциклопедія. URL: https://vue.gov.ua/Аналіз і синтез.

4. Серединська В. М., Загородна О. М., Федорович Р. В. Економічний аналіз : навч. посіб. / за ред. Р. В. Федоровича. Тернопіль: Астон, 2010. 624 с.

5. Управленческий учет : учеб. пособие / под ред. А. Д. Шеремета. Москва : ИД ФБКПРЕСС, 2002. $512 \mathrm{c}$.

6. Вахрушина М. А. Управленческий анализ : учеб. пособие. Москва : Омега-Л, 2010. 399 с.

7. Управлінський аналіз : навч. посіб. для студ. вищ. навч. закл. / за заг. ред. д-ра екон. наук, проф. 3. В. Герасимчук. Луцьк : Вежа-Друк, 2013. 1000 с.

8. Гайдаєнко О. М., Шевчук Н. С. Управлінський аналіз : навч. посіб. Одеса : ОНЕУ, ротапринт, 2015. $151 \mathrm{c}$.

9. Бороненкова С. А. Управленческий анализ : учеб. пособ. Москва : Финансы и статистика, 2003. $207 \mathrm{c}$.

10. Сич Є. М., Кравчук Г. В., Ільчук В. П. Управлінський аналіз діяльності суб'єктів господарювання : навч. посіб. Київ : ТОВ «Видавництво «Аспект-Поліграф», 2004. 204 с.

11. Томчук О. Ф. Управлінський аналіз: поняття, принципи та основні елементи. Проблеми системного підходу в економіці. 2019. Вип. 5(73), ч. 2. С. 133-142.

12. Самійленко Г. М., Вітер А. О. Роль та місце управлінського обліку та аналізу в системі управління підприємством. Юність науки - 2020: соціально-економічні та гуманітарні аспекти розвитку суспільства : збірник тез доповідей Х Міжнародної науково-практичної конференції студентів, аспірантів і молодих вчених (м. Чернігів, 23-24 квітня 2020 р.). Чернігів : НУ «Чернігівська політехніка», 2020. С. 275-276.

13. Томчук О. Ф., Мулик Т. О., Федоришина Л. І. Управлінський аналіз: сутність та значення у прийнятті рішень. Економіка, фінанси, менеджмент: актуальні питання науки і практики. 2019. № 4. C. 144-154.

\section{References}

1. Kychko, I.I., \& Kholodnytska, A.V. (2021). Motyvatsiinyi imperatyv realizatsii upravlinskykh kompetentsii ta zbalansuvannia rynku pratsi $\mathrm{v}$ Ukraini [Motivational imperative for the implementation of managerial competencies and balancing the labor market in Ukraine]. Problemy $i$ perspektyvy ekonomiky ta upravlinnia - Problems and prospects of economics and management, (1(25)), 7-14.

2. Kychko, I., Parubets, O., Kholodnytska, A., Perminova, V., \& Lytvyn, S. (2021). Formuvannia upravlinskykh kompetentsii kerivnykiv ta yikh vplyv na konkurentospromozhnist firmy i rynok pratsi $\mathrm{v}$ Ukraini [Formation of managerial competencies of managers and their impact on the competitiveness of the firm and the labor market in Ukraine]. Finansovo-kredytna diialnist: problemy teorii ta praktyky - Financial and credit activity: problems of theory and practice, (4(39)), 284-293. https://doi.org/10.18371/.v4i39.241317.

3. Polishchuk, O.P. (n.d.). Analiz i syntez. Velyka ukrainska entsyklopediia [Analysis and synthesis. Great Ukrainian encyclopedia]. https://vue.gov.ua/Аналіз і синтез.

4. Seredynska, V.M., Zahorodna, O.M., \& Fedorovych, R.V. (2010). Ekonomichnyi analiz [Economic analysis]. Aston.

5. Sheremet, A.D. (Ed.) (2002). Upravlencheskyi uchet [Management Accounting]. ID FBK-PRESS.

6. Vakhrushina, M.A. (2010). Upravlencheskyi analyz [Management analysis]. Omeha-L.

7. Herasymchuk, Z.V. (Ed.). (2013). Upravlinskyi analiz [Management analysis]. Vezha-Druk.

8. Haidaienko, O.M., \& Shevchuk, N.S. (2015). Upravlinskyi analiz [Management analysis]. ONEU. 
ТЕОРЕТИЧНІ ПРОБЛЕМИ РОЗВИТКУ НАЦІОНАЛЬНОЇ ЕКОНОМІКИ

9. Boronenkova, S.A. (2003). Upravlencheskyi analyz [Management analysis]. Finansy i statistika.

10. Sych, Ye.M., Kravchuk, H.V., \& Ilchuk, V.P. (2004). Upravlinskyi analiz diialnosti subiektiv hospodariuvannia [Management analysis of business entities]. TOV «Vydavnytstvo «Aspekt-Polihraf».

11. Tomchuk, O. F. (2019). Upravlinskyi analiz: poniattia, pryntsypy ta osnovni elementy [Management analysis: understanding, principle and basic elements]. Problemy systemnoho pidkhodu $v$ ekonomitsi - Problems of system approach in economy, 5(73)(2), 133-142.

12. Samiilenko, H.M., \& Viter, A.O. (2020). Rol ta mistse upravlinskoho obliku ta analizu v systemi upravlinnia pidpryiemstvom [The role of the management region and analysis in the management system of the enterprise]. In Yunist nauky - 2020: sotsialno-ekonomichni ta humanitarni aspekty rozvytku suspilstva: zbirnyk tez dopovidei X Mizhnarodnoi naukovopraktychnoi konferentsii studentiv, aspirantiv $i$ molodykh vchenykh - Science - 2020: Social, Economic and Humanitarian Aspects of Development of the Suspension: Collection of theses of the X International Scientific and Practical Conference of Students, Postgraduates and Young Parents] (pp. 275-276). NU «Chernihivska politekhnika».

13. Tomchuk, O.F., Mulyk, T.O., \& Fedoryshyna, L.I. (2019). Upravlinskyi analiz: sutnist ta znachennia u pryiniatti rishen [Management analysis: the day and night of the accepted solution]. Ekonomika, finansy, menedzhment: aktualni pytannia nauky i praktyky - Economics, finance, management: topical nutrition of science and practice, (4), 144-154.

Самійленко Галина Миколаївна - кандидат економічних наук, доцент, доцент кафедри менеджменту та державної служби, Національний університет «Чернігівська політехніка» (вул. Шевченка, 95, м. Чернігів, 14035, Україна).

Samiilenko Halyna - PhD in Economics, Associate Professor, Associate Professor of Department of Management and Public Service, Chernihiv Polytechnic National University (95 Shevchenka St., 14035 Chernihiv, Ukraine).

E-mail: galinamy@ukr.net

ORCID: https://orcid.org/0000-0001-6844-647X

ResearcherID: V-9327-2018

Вітер Аліна Олександрівна - здобувачка вищої освіти, Національний університет «Чернігівська політехніка» (вул. Шевченка, 95, м. Чернігів, 14035, Україна).

Viter Alina - Applicant for Higher Education, Chernihiv Polytechnic National University (95 Shevchenka Str., 14035 Chernihiv, Ukraine).

E-mail: alinchiksv46@gmail.com

Самійленко Г., Вітер А. Теоретико-методологічні засади управлінського аналізу та його роль у прийнятті управлінських рішень. Проблеми і перспективи економіки та управління. 2021. № 2(26). С. 37-47. 